\title{
MODEL KERJASAMA ACADEMIC, BUSINESS, GOVERMENT DAN CIVIL SOCIETY PADA KEBIJAKAN KERTAJATI AEROCITY
}

\author{
Waluyo Zulfikar1) \\ 1)Prodi Ilmu Administrasi Negara Universitas Nurtanio Bandung, Indonesia
}

\begin{abstract}
Abstrak
Pemerintah Provinsi Jawa Barat dalam rangka menciptakan inovasi dalam rangka percepatan capaian visi Gubernur Jawa Barat melalui pengembangan struktur prekonomian regional yang tangguh. Inovasi yang dimaksud adalah dengan melahirkan kebijakan berupa Peraturan Daerah Nomor 13 Tahun 2010 tentang Pembangunan dan Pengembangan Bandar Udara Internasional Jawa Barat dan Kertajati Aerocity. Berbagai upaya dilakukan oleh pemerintah Provinsi Jawa Barat dalam rangka mendorong percepatan pembangunan BIJB. permasalahan mengarah kepada permasalahaan pembebasan lahan yang terkendala karena penolakan sebagian warga terhadap pelaksanaan pembangunan BIJB dan Kertajati Aerocity. Permasalahaan lain juga timbul berkaitan dengan analisa terhadap kesiapan BIJB sebagai pengelola dan daya dukung pemerintah dalam mengimplementasikan kebijakan BIJB dan Kertajati Aerocity dan terkait dengan daya dukung sumber daya air yang penting untuk keberlangsungan keberadaan sebuah kawasan menjadi bahan pertimbangan untuk mengimplemtasikan BIJB dan Kertajati Aerocity di Kabupaten Majalengka Provinsi Jawa barat. Hal tersebut pada dasarnya memerlukan langkah strategis yang mumpuni demi terealisasikannya Kertajati aerocity di Kabupaten Majalengka. model kerjasama academic, business, goverment dan civil society pada kebijakan kertajati aerocity pada akhirnya dirasa mumpuni untuk merealisasikan program dan kebijakan kertajati aerocity.
\end{abstract}

Kata Kunci: BIJB, Kerjasama Daerah, Kabupaten Majalengka

\begin{abstract}
West Java Provincial Government in order to create innovation in order to accelerate the achievement of the vision of the Governor of West Java through the development of a strong regional economic structure. The innovation in question is to produce policies in the form of Regional Regulation Number 13 of 2010 concerning the Development and Development of West Java International Airport and Kertajati Aerocity. Various efforts have been made by the West Java Provincial government in order to accelerate the development of BIJB. The problem led to problems in land acquisition which was hampered by the rejection of some residents of the implementation of the BIJB and Kertajati Aerocity development. Another problem also arises related to the analysis of the readiness of the BIJB as the manager and support of the government in implementing BIJB and Kertajati Aerocity policies and related to the carrying capacity of water resources which are important for the sustainability of the existence of an area which is taken into consideration for implementing BIJB and Kertajati Aerocity in Majalengka Regency. West Java province. This basically requires qualified strategic steps for the realization of Kertajati aerocity in Majalengka Regency. The collaboration model of academic, business, government and civil society on Kertajati Aerocity policy is ultimately deemed qualified to realize aerocity Kertajati programs and policies.
\end{abstract}

Keywords: BIJB, Regional Cooperation, Majalengka Regency 


\section{PENDAHULUAN}

Penyelenggaraan pemerintah daerah diarahkan dalam rangka percepatan terwujudnya kesejahtraan masyarakat melalui peningkatan pelayanan publik dan peningkatan daya saing daerah. Penyelenggaraan Permerintah Daerah perlu ditingkatkan dengan memperhatikan aspekaspek hubungan antara pemerintah pusat dengan daerah dan antar daerah, potensi dan keanegaragaman daerah, serta peluang serta tantangan persaingan global dalam kesatuan sistem penyelenggaraan pemerintahaan negara. Hal tersebut sebagaimana tertuang didalam dasar pertimbangan lahirnya Undang-Undang Nomor 23 Tahun 2014 tentang Pemerintah Daerah sebagaimana telah diubah melalui Undang-Undang Nomor 9 Tahun 2015 Tentang Perubahan Kedua Atas Undang-Undang 23 Tahun 2014 tentang Pemerintahan Daerah.

Pemerintah pusat mendorong Pemerintah Daerah untuk mengoptimalkan potensi wilayah dan inovasi public sektor dalam rangka percepatan pembangunan wilayah. Hal tersebut sebagaimana ketentuan yang ada pada Pasal 390 Undang-Undang-Undang Nomor 23 Tahun 2014 tentang Pemerintahaan Daerah yang pada akhirnya dipertegas dengan lahirnya Peraturan Pemerintah Nomor 38 Tahun 2017 tentang Inovasi Daerah. Pemerintah Daerah sebagai penyelenggara urusan pemerintahaan di daerah dituntut untuk menciptakan berbagai inovasi daerah yang memiliki keterkaitan dengan semua bentuk pembaharuan dalam penyelenggaraan Pemerintah Daerah.

Pemerintah Provinsi Jawa Barat dalam rangka menciptakan inovasi dalam rangka percepatan capaian visi Gubernur Jawa Barat dalam bentuk akselerasi peningkatan kesejahtraan masyarakat melalui pengembangan struktur prekonomian regional yang tangguh, melakukan berbagai upaya peningkatan infrastruktur wilayah yang pada akhirnya diharapkan dapat menunjang kelancaran aktivitas sosial dan ekonomi masyarakat di Jawa Barat. Inovasi yang dimaksud adalah dengan melahirkan kebijakan berupa Peraturan Daerah Nomor 13 Tahun 2010 tentang Pembangunan dan 
Pengembangan Bandar Udara Internasional Jawa Barat dan Kertajati Aerocity. Bandara udara Internasional Jawa Barat yang kemudian disingkat BIJB sampai dengan saat ini telah selesai dibangun. Berbagai upaya dilakukan oleh pemerintah Provinsi Jawa Barat dalam rangka mendorong percepatan pembangunan BIJB. Adapun maksud dan tujuan pembangunan dan pengembangan BIJD serta Kertajati Aerocity sebagaimana tertuang didalam Pasal 3 Peraturan Daerah Provinsi Jawa Barat Nomor 13 Tahun 2010 yaitu sebagai berikut :

a. Mendorong pengembangan wilayah pembangunan CIAYUMAJAKUNING (Cirebon, Indramayu, Majalengka dan Kuningan)

b. Meningkatkan pertumbuhan ekonomi regional berbasis potensi daerah.

c. Meningkatkan daya saing global Jawa Barat dalam rangka mendorong percepatan pertumbuhan investasi.

d. Meningkatkan pelayanan kepada masyarakat di bidang transportasi udara.

e. Meningkatkan investasi, industri, perdagangan, pariwisata, pemukiman dan perluasan lapangan kerja.

\section{METODE PENELITIAN}

Metodologi yang akan digunakan untuk menganalisa permasalahan pelayanan ini menggunakan pendekatan analisa deskriptif. Dilihat dari permasalahan yang menjadi fenomena dalam penelitian ini, dituntut untuk mampu merumuskan rekomendasi sebagai bahan penyusunan dokumen kebijakan dalam terciptanya model kerjasama dalam pengembangan bandara kertajati di Kabupaten Majalengka. Diharapkan dengan pendekatan analisa deskriptif dapat melahirkan output Penelitian yang sesuai dengan tujuan penelitian. 


\section{HASIL DAN PEMBAHASAN}

Arah kebijakan Kertajati Aerocity meliputi pembangunan bandara udara dan kawasan perkotaan yang merupakan bagian dari upaya mendukung terwujudnya pusat kegiatan nasional (PKN) Cirebon serta penataan Kawasan Strategis Provinsi Jawa Barat (KSP) Koridor BandungCirebon sebagai bagian dari kebijakan penataan ruang Provinsi Jawa Barat. Hal ini sebagaimana tertuang didalam Peraturan Pemerintah Nomor 26 Tahun 2008 tentang Rencana Tata Ruang Wilayah Nasional, Peraturan Menteri Perhubungan Nomor KM 49 Tahun 2009 tentang Rencana Pembangunan Jangka Panjang Kementerian Perhubungan dan Keputusan Menteri Perhubungan Nomor 7 Tahun 2010 tentang Rencana Strategis Kementerian Perhubungan Tahun 2010-2014 yang selanjutnya telah ditegaskan kembali dalam Peraturan Daerah Provinsi Jawa Barat Nomor 8 Tahun 2008 tentang Rencana Pembangunan Jangka Panjang Daerah Provinsi Jawa Barat Tahun 2005-2025. Pembangunan dan Pengembangan BIJB serta Kertajati Aerocity dalam implementasinya melibatkan berbagai pihak, hal ini dikarenakan nilai strategis dari keberadaan BIJB dan Kertajati Aerocity yang diharapkan dapat mendorong pertumbuan perekonomian dan pengembangan wilayah CIAYUMAJAKUNING. Sebagaimana pasal 4 ayat (2) Peraturan Daerah Provinsi Jawa Barat Nomor 13 Tahun 2010 menerangkan bahwa pembangunan dan pengembangan BIJB dan Kertajati Aerocity terintegrasi dengan berbagai program strategis nasional lainnya yaitu :

a. rencana pembangunan infrastruktur jalan tol CISUMDAWU (Cileunyi-Sumedang-Dawuan) dan jalan akses dari dan menuju kawasan Kertajati Aerocity;

b. rencana pembangunan infrastruktur rel kereta api;

c. pembangunan infrastruktur sumberdaya air, energi, telekomunikasi, transportasi, permukiman dan infrastruktur lainnya; dan

d. pengembangan pelabuhan di Daerah. 
Untuk lebih jelasnya terkait dengan konsep Kertajati Aerocity sebagaimana divisualisasikan pada gambar 1.1 Berikut :

Gambar 1.1 : Maping Plan Kertajati Aerocity

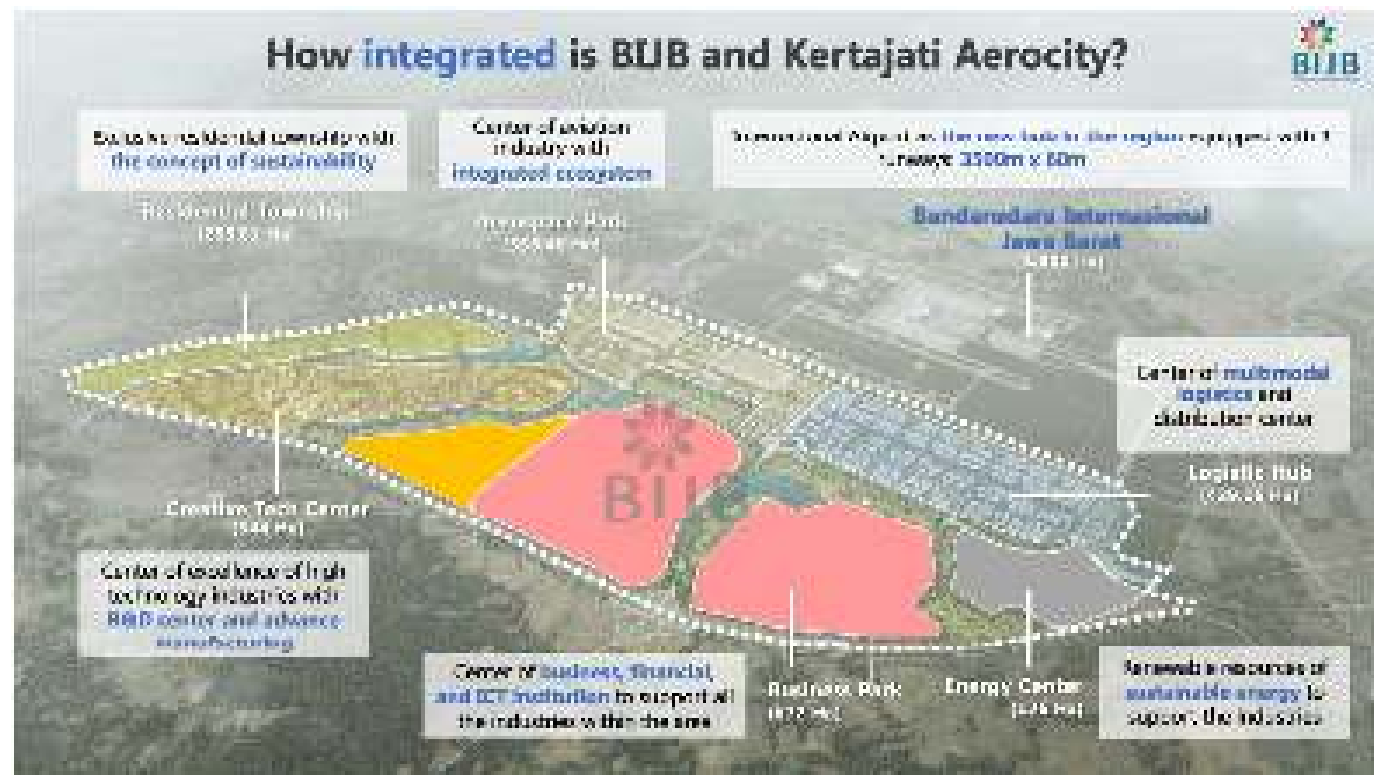

Sumber : Data BIJB 2018

Visualisasi konsep Kertajati Aerocity yang ada pada Gambar 1.1 memiliki kemiripan dengan konsep aerotropolis yang telah lama dikembangkan dalam rangka mendukung keberadaan kawasan bandara. Hal ini sebagaimana divisualisasikan pada Gambar 1.2 berikut ini :

Gambar 1.2 : Maping Plan Aerotropolis

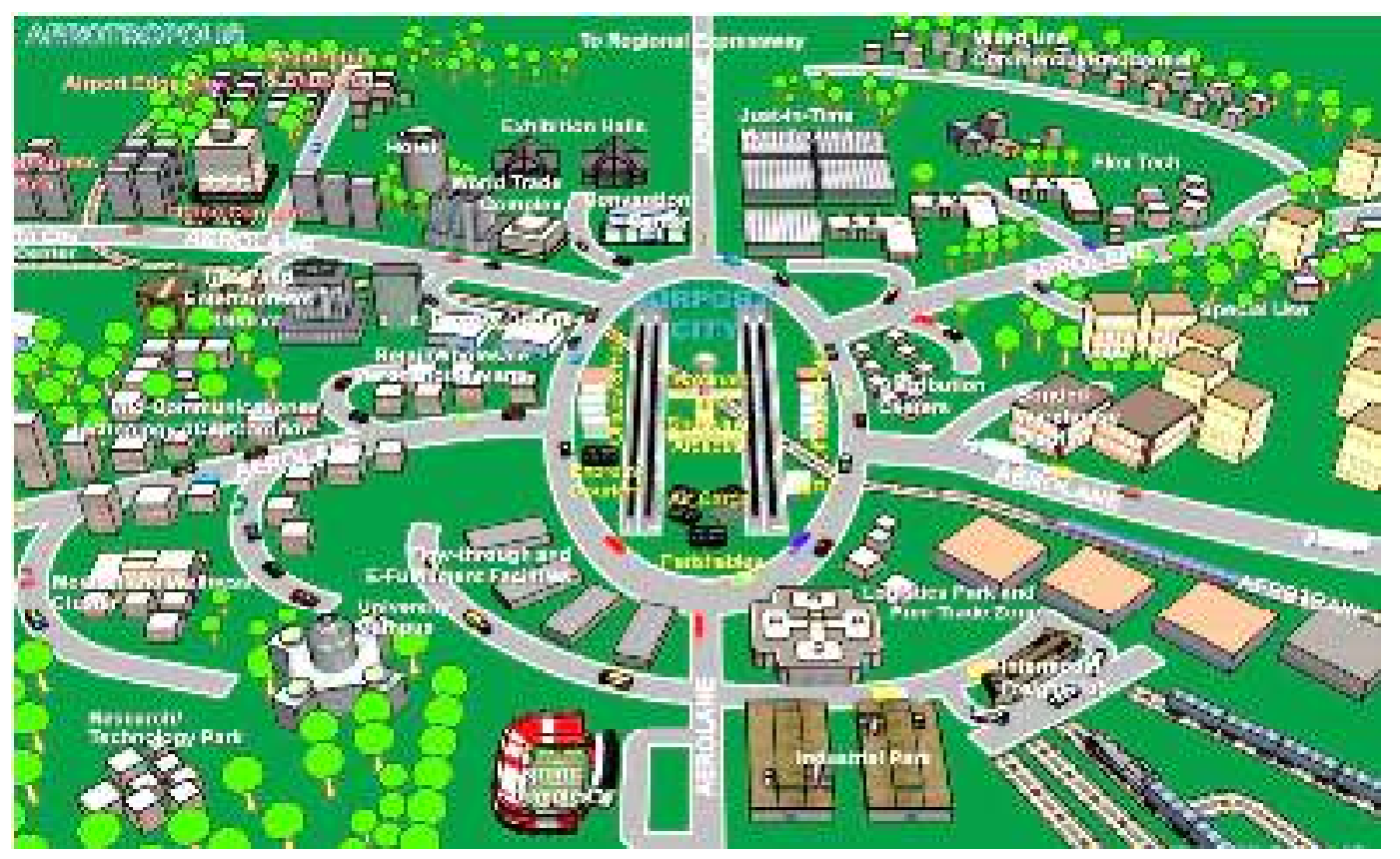


Sumber : Kasarda, John D., "The Way Forward," Global Airport Cities, 2010.

Sebagaimana visualisasi pada gambar 1.1 dan gambar 1.2 menunjukan bahwa kondisi yang ada pada aerotropolis (bandara kota) dan aerocity (kota bandara) memiliki kesamaan, yaitu bandara menjadi titik simpul penting dalam mengoptimalkan sistem komersial dan produksi global serta memiliki peran untuk mengembangkan ekonomi lokal yang menarik berbagai macam bisnis-komersial berbasis transportasi udara ke dalam lingkungan sekitar bandara (Kasarda, 2001: 42). Namun ada hal-hal lainnya yang membedakan antara konsep aerotropolis dan aerocity. Perbedaan tersebut dikemukakan oleh Kasarda (2001; 4-5) menyebutkan evolusi "bandara kota" menjadi "kota bandara" didorong oleh apa yang dia sebut sebagai airport city drivers. Menurut Kasarda Kota Bandara telah berevolusi dengan bentuk spasial yang berbeda didasarkan pada lahan yang tersedia dan prasarana transportasi darat, namun hampir semua muncul sebagai tanggapan terhadap empat pendorong pembangunan yang menjadi pertimbangan utama. Keempat airport city driver tersebut menurt Kasarda (2001; 4-5) adalah:

1. Bandara-bandara perlu menciptakan sumber daya dari kegiatan yang tidak berkaitan dengan penerbangan, untuk bersaing dan juga memberikan pelayanan yang lebih baik dari fungsi bandara.

2. Usaha sector komersial untuk mendapatkan lahan yang aksesibel

3. Bandara mampu meningkatkan penumpang dan barang

4. Pelayanan bandara sebagai katalis dan magnet untuk pembangunan kegiatan bisnis.

Di Indonesia, pembangunan bandara dengan menggunakan konsep aerocity merupakan hal yang baru. Hal ini sebagaimana tertuang didalam Peraturan Pemerintah Nomor 13 Tahun 2017 Tentang Perubahan Atas Peraturan Pemerintah Nomor 26 Tahun 2008 tentang Rencana Tata Ruang Wilayah Nasional, Pembangunan Bandara Udara Baru di Indonesia dengan mengacu pada konsep aerocity ada di tiga lokasi bandara udara yaitu 
sebagai berikut : 1) Bandara Kertajati di wilayah Provinsi Jawa Barat, 2) Bandara Internasional di Propinsi D.I. Yogyakarta, 3) Bandara Udara Syamsuddin Noor di provinsi Kalimantan Selatan.

Perencanaan pembangunan kertajati aerocity telah ditetapkan pula didalam Peraturan Presiden Nomor 28 Tahun 2012 Tentang Rencana Tata Ruang Pulau Jawa - Bali ${ }^{1}$ dan Peraturan Daerah Nomor 22 Tahun 2010 Tentang Rencana Tata Ruang Wilayah Provinsi Jawa Barat Tahun 200920292. Kedua kebijakan tersebut, menerangkan bahwa kertajati aerocity akan terhubung dengan jalan ateri primer kawasan perkotaan nasional di wilayah CIAYUMAJAKUNING, hal ini semakin memperkuat keberadaan BIJB untuk mendukung wilayah priangan timur untuk pengembangan sektor strategis yang menjadi tujuan utama didirikannya BIJB Kertajati.

Pembangunan dan pengembangan bandara udara internasional jawa barat, sebagaimana telah dikemukakan diawal pembahasan penelitian ini ditetapkan melalui Peraturan Daerah Provinsi Jawa Barat Nomor 13 Tahun 2010 tentang Pembangunan dan Pengembangan Bandara Udara Internasional Jawa Barat dan Kertajati Aerocity yang kemudian diimplementasikan dengan peraturan yang lebih teknis yang mengatur tentang pelaksanaan kelembagaan yang mengelola dan melaksanakan pengembangan BIJB melalui Peraturan Daerah Provinsi Jawa Barat Nomor 22 Tahun 2013 tentang Pembentukan Badan Usaha Milik Daerah Pengelola Bandara Udara Internasional Jawa Barat dan Kertajati Aerocity. Hal ini merupakan hal yang baru di Indonesia, mengingat selama ini pengelolaan bandara udara mayoritas dikelola oleh BUMN Angkasapura. BIJB sebagai

\footnotetext{
${ }^{1}$ Peraturan Presiden Nomor 28 Tahun 2012 Tentang Rencana Tata Ruang Pulau Jawa - Bali. Dalam Perpres ini disebutkan : "Pasal 21, Ayat 7, butir g : Pengembangan dan pemantapan jaringan jalan nasional yang menghubungkan kawasan perkotaan nasional dengan pelabuhan dan/atau bandar udara yaitu Jaringan jalan arteri primer yang menghubungkan PKW Kadipaten dengan Bandar Udara Kertajati (Majalengka).”

2 Peraturan Daerah Nomor 22 Tahun 2010 Tentang Rencana Tata Ruang Wilayah Provinsi Jawa Barat Tahun 2009-2029, yang menyebutkan :

a) Pasal 56, Ayat 2, Butir d. : Kabupaten Majalengka, diarahkan menjadi lokasi Bandara Internasional Jawa Barat dan Aerocity di Kertajati, daerah konservasi utama Taman Nasional Gunung Ciremai, serta untuk kegiatan agrobisnis dan industri bahan bangunan, dan pertambangan mineral serta pengembangan sarana dan prasarana yang terintegrasi di PKW Kadipaten.

b) Pasal 56, Ayat 3, Butir f.1.g) : Pembangunan kawasan permukiman di Kertajati Aerocity Kabupaten Majalengka.

c) Pasal 56, Ayat 3, Butir g. : Pengembangan Kawasan Industri Kertajati Aerocity di Kabupaten Majalengka.
} 
lembaga teknis pengelola bandara udara diharapkan dapat medorong peningkatan pendapatan asli daerah Provinsi Jawa Barat.

Bidang kegiatan BIJB secara umum sebagaimana tertera di Pasal 9 Peraturan Daerah Nomor 22 Tahun 2013 tentang Pembentukan Badan Usaha Milik Daerah Pengelola Bandara Udara Internasional Jawa Barat dan Kertajati Aerocity meliputi 2 hal sebagai berikut :

a. Pengusahaan kebandaraudaraan, meliputi perencanaan, pembangunan, pengoprasiaan dan pengelolaan, pemeliharaan serta pengembangan.

b. Pengusahaan Kertajati Aerocity, meliputi perencanaan, pembangunan, pengoprasiaan dan pengelolaan, pemeliharaan serta pengembangan.

Sebagaimana pasal 9 ayat 1 huruf a dab b tersebut, BIJB tidak hanya berfokus kepada keberadaan bandara udara, tapi juga bertanggung jawab dalam hal perencanaan, pembangunan, pengoprasian, pengelolaan, pemeliharaan dan pengembangan Kertajati Aerocity. Keberadaan BIJB sebagai kepanjangan tangan pemerintah Provinsi Jawa Barat dalam merealisasikan konsep aerocity, yang juga merupakan bagian dari wacana pemekaran wilayah Kabupaten Majalengka menjadi Kabupaten Majalengka dan Kota Majalengka. ${ }^{3}$ Hal ini merupakan bagian dari wacana pengembangan konsep aerocity yang yang berangkat dari pemahaman konsep airport city drivers. Sebagaimana telah disampaikan pada bagian awal, pemikiran John Kasarda yang tentang pendirian Kota Bandara telah berevolusi dengan bentuk spasial yang berbeda didasarkan pada lahan yang tersedia dan prasarana transportasi untuk pengembangan wilayah. Pemahaman tersebut pada akhirnya terus berkembang mengingat peran serta fungsi dari keberadaan sebuah bandara yang tidak hanya sebatas sebagai jalur lalu lintas penerbangan, dijelaskan oleh Kasarda (2001: 43) "As more and more businesses cluster around these airports and along transportation corridors radiating from them a new urban form is emerging the

\footnotetext{
${ }^{3}$ Pikiran Rakyat 26 Februari 2017

(http://www.pikiran-rakyat.com/jawa-barat/2017/02/26/kertajati-aero-city-terbentuk-majalengka-akan-dibagikabupaten-kota-394587) Diakses Tanggal 22 Oktober 2018
} 
Aerotropolis." Kawasan sekitar bandara internasional semakin memicu pertumbuhan kluster-kluster industri dan usaha sepanjang koridor menuju dan dari bandara membentuk urban form tersendiri. Perubahan evolutif dari keberadaan bandara digambarkan Kasarda dan Lindsay sebagai berikut:

Many aerotropoli will evolve out of the cities we already call home-only their highways and byways will lead us to terminals instead of downtown. For isntant ones like New Songdo, Kasarda has drafted a set of blue prints replete with air trains and "aerolanes" connecting prefab neighborhoods and business district. (Kasarda dan Lindsay, $2001 ; 5)$.

Sebagaimana perkembangan yang ada didalam konsep aerotropolis pada akhirnya melahirkan paradigma baru dalam aktivitas kebandaraan. Pengembangan kawasan komersial yang pesat di sekitar bandara, menjadikan bandara sebagai generator pertumbuhan perkotaan dan menjadikan bandara sebagai pusat lapangan pekerjaan yang penting, kawasan perbelanjaan, perdagangan serta destinasi bisnis, serta bandara membangun sebuah "brand image" tersendiri untuk menarik kegiatan bisnis yang tidak berkaitan dengan kebandar udaraan yang pada akhirnya melahirkan konsep aerocity. Kegiatan komersial di dalam kawasan bandara merefleksikan kebutuhan dari pekerjaan, pekerja dan penduduk terhadap pelayanan yang disediakan oleh bisnis yang berbasis bandara. pelayananpelayanan tersebut meliputi pelayanan perumahan, rekreasi, kuliner, perdagangan, kesehatan, penitipan anak dan lainnya. Seperti pada penelitian mengenai perkotaan di Amerika Serikat yang memaparkan mengenai pertumbuhan di area perkantoran di dekat bandara lebih cepat berkembang dibandingkan di área bandara sub-urban lainnya (Kasarda, 2010:12). Konsep aerocity bukanlah hal yang baru, sampai dengan tahun 2018 telah banyak dibangun Aerotropolis dan Aerocity sebagai bagian dari konsep yang dikembangkan oleh John Kasarda yang divisualisasikan sebagaimana gambar berikut ini : 
Gambar 1.3 : Aerotropolis \& Aerocity In Global World

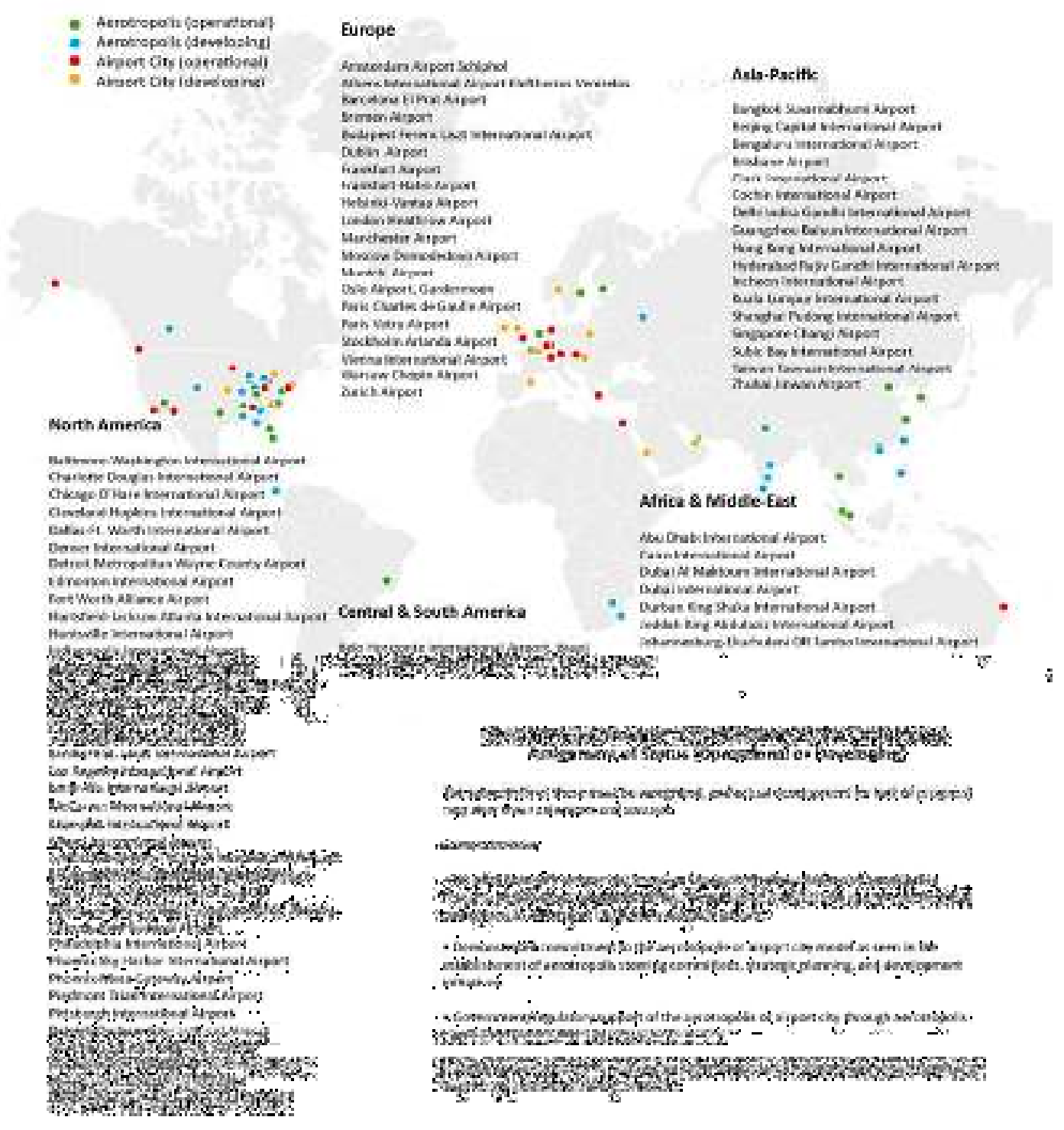

Sumber : Data Penelitian (2018) 4

Sebagaimana gambar yang ada pada gambar 1.3 tersebut setidaknya berdasarkan hasil tabulasi data yang peneliti kembangkan dari penelitian john kasarda. Sampai dengan tahun 2018 total jumlah aerotropolis dan aerocity yang sudah berjalan dan sedang dalam tahap pembangunan sebagaimana tabel berikut ini :

\footnotetext{
${ }^{4}$ John Kasarda (www.aetropolis.com) Diakses pada tanggal 19 Oktober 2018 Pukul 13.20. Penelitian John Kasarda terfokus pada pengembangan konsep dan struktur pola ruang serta kebijakan publik yang mengatur tentang aetropolis. Setidaknya berdasarkan data hasil pemetaan John Kasarda pada tahun 2010 terdapat 19 aerotropolis yang sudah beroprasional, 22 aerotropolis yang sedang dalam proses pembangunan, 18 aerocity yang sudah beroprasional dan 14 aerocity yang sedang dalam proses pembangunan.
} 
Tabel 1.1 : Jumlah Aerotropolis dan Aerocity di Dunia (2010)

\begin{tabular}{|l|l|l|l|l|}
\hline & $\begin{array}{l}\text { Aerotropolis } \\
\text { Oprational }\end{array}$ & $\begin{array}{l}\text { Aerotropolis } \\
\text { Develoving }\end{array}$ & $\begin{array}{l}\text { Aerocity } \\
\text { Oprational }\end{array}$ & $\begin{array}{l}\text { Aerocity } \\
\text { Develoving }\end{array}$ \\
\hline Jumlah & 19 & 22 & 18 & 17 \\
\hline
\end{tabular}

Sumber : Data Penelitian (2018)

Sebagaimana data yang ada pada tabel 1.1 menunjukan kondisi perbandingan jumlah aerotropolis dan aerocity yang ada di dunia. Berdasarkan data tersebut, memperkuat argumentasi bahwa pembangunan kertajati aerocity pada dasarnya bukanlah hal yang baru, setidaknya sudah ada 18 aerocity di dunia yang telah beroprasional dan 17 aerocity yang sedang dalam tahap pengembangan 3 diantaranya ada di Indonesia.

Penelitian terkait dengan model aerocity sebagaimana telah dikemukakan sebelumnya banyak dikaji oleh John Kasarda5. Penelitian John Kasarda lebih banyak menganalisa dan mengamati perkembangan model aerocity yang ada di seluruh dunia. John Kasarda dalam berbagai hasil penelitiannya juga mengangkat perubahan fenomena public transport dari aerotropolis menjadi aerocity dan memetakan konsep airport city driver, pemikiran-pemikiran John Kasarda yang pada akhirnya banyak diadopsi oleh berbagai negara untuk mengembangkan aerotropolis dan aerocity termasuk konsep tata ruang aerocity yang dikembangkan di Indonesia.

Penelitian lainnya terkait dengan permasalahaan dalam pelaksanaan pembangunan dan pengembangan BIJB pada dasarnya telah dilakukan oleh para peneliti sebelumnya. Dicky Saromi $(2012)^{6}$ melakukan penelitian dengan memfokuskan pada masalah implementasi kebijakan pembebasan lahan pada beberapa desa di Kecamatan Kertajati Kabupaten Majalengka. Permasalahaan yang diangkat pada dasarnya berangkat dari adanya beberapa desa di Kecamatan Kertajati yang menolak pembebasan tanah untuk pembangunan Bandara Udara Internasional Jawa Barat. Penelitian tersebut pada akhirnya memberikan gambaran tentang permasalahaan yang ada dalam hal pembebasan lahan dan membangun konsep baru

\footnotetext{
${ }^{5}$ Kasarda, John ; Lindsay. "The Way Forward," Global Airport Cities, 2010

${ }^{6}$ Dicky Saromi (Disertasi UNPAD) Pada Tahun 2012 melakukan penelitian dengan judul "Implemerntasi Kebijakan Pembebasan Lahan untuk pembangunan bandara udara internasional Jawa Barat di Desa Kertajati, Bantarjati, Kertasari dan Sukamulya".
} 
berupa temuan terkait dengan upaya menangani permasalahaan, khususnya untuk pembebasan lahan untuk kepentingan infrastruktur Bandara Internasional Jawa Barat.

Penelitian terdahulu lainnya yang juga telah di konfrensikan dan dipublikasikan secara internasional dilakukan secara bersama oleh Yadi Suryadi, Asrini Chrysanti, Febya Nurnadiati, Mohammad Bagus Adityawan dan Arno Adi Kuntoro ${ }^{7}$ (2018). Penelitian ini mengkaji tentang alokasi kebutuhan sumber daya air untuk mendukung oprasional Bandara Udara Internasional Jawa Barat dan Kertajati Aerocity. Dalam penelitiannya lebih mengkaji tentang hal teknis yang berkaitan dengan sumber daya air yang ada di sekitar BIJB dan Kertajati Aerocity. Penelitian ini juga menggunakan analisa dengan pendekatan konsep water balance, water demand, and also water allocation using WEAP (Water Evaluation and Planing) Hasil penelitian ini, menunjukan bahwa kondisi ketersedian air dengan model simulasi WEAP menunjukan bahwa sungai cimanuk yang ada di wilayah sekitar BIJB dan Kertajati Aerocity hanya mampu bertahan memberikan pasokan air hingga 2040.

Penelitian lainnya yaitu penelitian berkelompok yang dilakukan oleh M Ikshsan Setiawan et all ${ }^{8}$. Penelitian ini dilaksanakan dalam rangka menganalisa korelasi hubungan antara keberadaan BIJB dengan Gross Domestic Product-Regional (GDP-regional) performance. Penelitian ini menggunakan pendekatan kuantitatif. Hasil penelitian ini menunjukan bahwa kinerja bandar udara yang baik harus mempertimbangkan pasokan air, pembuangan limbah, pengembangan kegiatan perdagangan, area perbaikan kendaraan bermotor, lembaga keuangan dan asuransi, aktivitas bisnis, administrasi pertanahan, pendidikan, pelayanan kesehatan dan pelayanan lainnya.

\footnotetext{
${ }^{7}$ Suryadi, Adi dkk. Melakukan Penelitian Bersama dengan Judul "Water Resources Allocation for Kertajati, Jatitujuh, and Ligung Sub-Districts to Support the Development of West Java International Airport (BIJB) and Kertajati Aerocity Area" https://doi.org/10.1051/matecconf/201814703010 Diakses Tanggal 22 Oktober 2018 Pukul 12.39

${ }^{8}$ Penelitian M I Setiawan et al 2018 IOP Conf. Ser.: Earth Environ. Sci.140 012089 , Dengan Judul The Correlations between Airport Sustainability and Indonesian Economic Growth. IOP Publisher Sumber : http://iopscience.iop.org/article/10.1088/1755-1315/140/1/012089/pdf Diakses Tanggal 22 Oktober 2018 Pukul 12.57
} 


\section{KESIMPULAN}

Berdasarkan analisa terhadap penelitian terdahulu, fokus permasalahan mengarah kepada permasalahaan pembebasan lahan yang terkendala karena penolakan sebagian warga terhadap pelaksanaan pembangunan BIJB dan Kertajati Aerocity. Permasalahaan lain juga timbul berkaitan dengan analisa terhadap kesiapan BIJB sebagai pengelola dan daya dukung pemerintah dalam mengimplementasikan kebijakan BIJB dan Kertajati Aerocity dan terkait dengan daya dukung sumber daya air yang penting untuk keberlangsungan keberadaan sebuah kawasan menjadi bahan pertimbangan untuk mengimplemtasikan BIJB dan Kertajati Aerocity di Kabupaten Majalengka Provinsi Jawa barat. Hal tersebut pada dasarnya memerlukan langkah strategis yang mumpuni demi terealisasikannya Kertajati aerocity di Kabupaten Majalengka. model kerjasama academic, business, goverment dan civil society pada kebijakan kertajati aerocity pada akhirnya dirasa mumpuni untuk merealisasikan program dan kebijakan kertajati aerocity.

\section{DAFTAR PUSTAKA}

Abdulsyani, 1994. Sosiologi Skematika, Teori, dan Terapan, Jakarta: Bumi Aksara

Abdurahman, Benjamin, 2005. Pemahaman Dasar Regional Management \& Regional Marketing, IAP.

Dunn, William N. 1999. Analisis Kebijakan Publik. Yogyakarta: Gadjah Mada University Press

Edwards G. 2003. Implementasi Kebijakan Publik. Yogyakarta: Lukman Offset

Etzkowitz, H., \& Leydesdorff, L. 1995. The Triple Helix-UniversityIndustry-Government Relations: A Laboratory for Knowledge-Based Economic Development. EASST Review

Fandi Tjipto, 1994. Total Qualiti Management. Yogyakarta: Andi Offset.

Kuncoro, 2004. Mudrajad, Otonomi dan Pembangunan Daerah, Reformasi, Perencanaan, Strategi dan Peluang, Erlangga 
Pamudji, 1985. Kerjasama Antar Daerah Dalam Rangka Pembinaan WilayahSuatu Tinjauan dari Segi Administrasi Negara, PT. Bina Aksara,Jakarta

Pratikno, et.al. 2004. Mengelola Dinamika Politik dan Sumberdaya Daerah, Yogyakarta: PLOD Departemen Dalam Neger London: Sage Publications, International Educational and Professional

Santosa, Panji.2008. Administrasi Publik (Teori dan Aplikasi Good Govarnance). Bandung: PT Refika Aditama

Siagian, Sondang P.2003. Manajemen Sumber Daya Manusia. Jakarta: Bumi Aksara.

2009. Administrasi Pembangunan (Konsep, Dimensi, dan Strateginya). Jakarta: PT Bumi Aksara

Sinaga, Obsatar.2010. Otonomi Daerah \& Kebijakan Publik (Implementasi Kerja Sama Internasional). Bandung: Lespsindo.

Steers, Richard.1985. Efektivitas Organisasi. Jakarta: Erlangga.

Subarsono, A.G.2005. Analisis Kebijakan Publik Konsep, Teori dan Aplikasi. Yogyakarta : Pustaka Pelajar

Tachjan.2006. Implementasi Kebijakan Publik. Bandung: AIPI Bandung dan KP2W Lemlit Unpad.

Tangkilisan, Hesel Nogi S.2003. Kebijakan Publik yang Membumi. Yogyakarta: Lukman Offset.

Nugroho, D. Rian.2004. Kebijakan Publik: Formulasi, Implementasi, dan Kebijakan. Jakarta: Gramedia. .2006, Kebijakan Publik Untuk Negara-Negara Berkembang. Jakarta: Gramedia

Nuryulia Praswati, Aflit. 2017. Perkembangan Model Helix Dalam Peningkatan Inovasi. Sukoharjo:,Fakultas Ekonomi dan Bisnis Universitas Muhammadiyah Surakarta

Wahab, Solichin A.2004. Analisa Kebijakan dari Formulasi ke Implementasi Kebijakan Negara. Jakarta : Bumi Aksara

Wibawa, Samodra.1994. Evaluasi Kebijakan Publik. Jakarta: Raja Grafindo Persada

Widjajani, dkk. 2017. Model Quadruple Helix Sebagai Model Inovasi Daerah (Kajian Literatur) Bandung: Universitas Langlangbuana Bandung

Winarno, Budi.2008. Kebijakan Publik Teori dan Proses. Jakarta: Buku Kita

Winarso, Haryo et al, 2002, Pemikiran dan Praktek Perencanaan dalam Era Transformasi di Indonesia, Departemen Teknik Planologi ITB, Yayasan Sugijanto Soegijoko. 
Yeremias T. Keban, 2009, Kerjasama Antar Pemerintah Daerah dalam Era otonomi: Isu, Strategis, Bentuk dan Prinsip, Dapat dibuka di situs:http://www .bappenas.go.id/node/48/2258/kerjasama pemerintah-daerah

\section{Peraturan Perundang-undangan}

Peraturan Pemerimah Republik Indonesia Nomor 28 Tahun 2018 Tentang Kerja Sama Daerah

Peraturan Daerah Nomor 13 Tahun 2010 tentang Pembangunan dan Pengembangan Bandar Udara Internasional Jawa Barat dan Kertajati Aerocity 